\title{
A Strategy to Overcome Loandependency to the Moneylenders (Research of Employees at Industrial Companies in Banten Province)
}

\author{
Junet Kaswoto* \\ Islamic Economics and Finance, Trisakti University, Jakarta, Indonesia \\ PO box 11440, Jl. Kyai Tapa, RT.06/RW.016, Jakarta, Indonesia
}

Miyasto

Faculty of Economics and Business, Diponegoro University, Semarang, Indonesia PO box 50275, J1. Prof Sudarto, Tembalang, Semarang, Indonesia

Hasbi Umar

Sharia Faculty, Sultan ThahaSaifuddin State Islamic University, Jambi, Indonesia PO box 36361, Jl. Arif Rahman Hakim, Simpang IV Sipin, Jambi, Indonesia

\begin{abstract}
One of the economic diseases of society in human civilization is usury. Difficulties in a community in the lending money to some financial industry services, especially in the banking industry, have become a target for a moneylender in offering their services. The moneylenders' main motivation was to make other people's difficulties in a business field that benefits themselves. The dilemma of people's socio-economic life, especially among company employees, was related to financial problems, it caused employees to need sudden funds to meet their daily needs. This research aimed to analyze the effect of religiosity factor, cultural factor, social factor, personal factor, psychological factor, and the existence of Sharia Micro Finance Institution (SMFI) on loan dependency to the moneylenders, this research aimed to formulate a strategy to overcome loan dependency to the moneylenders. The type of research method in this paper was a combination of the type of investigation and the unit of analysis because this research analyzed the effect and simultaneous relationship between several studied variables using cross-section type data. The methods used in this research were SEM (Structural Equation Modeling).The results showed that religiosity factor, cultural and social factors did not have a significant effect on loan decision making. Meanwhile, personal factor, psychological factor, and the existence of SMFI factor have a significant effect on loan decisions. To reduce the dependency of employees on taking loan from the moneylenders, companies are expected to provide awareness of saving and caring for others through Islamic philanthropy. The Novelty in this research was that the religiosity factor did not have a significant effect on loan dependency to the moneylenders for employees at industrial companies in Banten.
\end{abstract}

Keywords: moneylenders, usury, structural equation modeling

DOI: $10.7176 / \mathrm{EJBM} / 13-6-05$

Publication date:March $31^{\text {st }} 2021$

\section{Introduction}

\subsection{Introduce the Problem}

One of the economic diseases of a society that has been known for a long time in human civilization is usury. Some economists estimate that usury has been around since humans knew money/gold and silver (Tarmizi, 2017). Usury is an advantage that occurs in exchange for similar goods (Sulaemang, 2015; Wahab, 2017) or barter trading accompanied by these rewards and advantages is required in the agreement (Khakim, 2020). If the excess is not required in the agreement then it does not include as usury. The source of funds owned by the moneylenders in carrying out their business comes from their own capital (Parlina, 2017),Moreover of other people's loans with high interest rates. The Moneylenders provide loan for agriculture, trade, handicrafts and also consumption (Setiowati, 2017). In Islam, the practice of the moneylenders is the same as the term of mu'amalatribawiyah which is in the addition to the capital of money arising from a transaction of debt receivables that must be given by the borrower to the owner of the money at the time the debt is due. As written by Khasanah (2019)that in practice the moneylenders do not cooperate, but only make one of the parties who work hard to repay the loan.

The practice of the moneylenders mushrooming among employees or industrial employees in Banten province is due to one of the economic growth in Banten is supported by the existence of formal sectors such as industrial companies that become sources of Regional Native Income (PAD) and employment providers in Banten Province. The burden felt by the employees can be both physical and mental (Hariyati, 2011). The mental burden suffered by the employees, among others, is stress caused by financial problems. The financial problems often put employees at an unbearable strain. For some employees, this financial problem is persisted and never solved. 
Unpaid bills and installments, for example, will create severe pressures and often lead to divorce or poor job performance (Iswanto, 2005).

According to Chavalisakulchi and Sahvanaz, as written in (Hariyati, 2011). Work fatigue is a complex phenomenon caused by biological factors in the work process and affected by internal and external factors. Because of work fatigue, when employees come to home, they use their time to take a rest with family and have little time to socialize with the community or their environment. This is the cause of the behavior of borrowing to the moneylenders. However, several actions have monitored the practice of the moneylenders in Banten, for instance, the Head of the Serang Regency Trade and Industry Cooperative Office, which started to collect data on the existence of the moneylenders under the guise of cooperatives in Serang Regency, because they received many complaints and reports on the existence of the moneylenders who ensnare people with high debt interest. Usually the moneylenders work by offering capital to small traders such as in the market (vegetable traders, fish, meat and others), street vendors, hawkers and other small businesses (Qodarini, 2013; Sibero, 2015).

\subsection{Explore Importance of the Problem}

This research focused on employees of the industrial companies / factories as consumers or service users of the moneylenders who offer loan services on a high interest rates. This is because consumers or users of the moneylenders services from companies' employees are quite high, especially in Banten province. According to Keller and (Kotler, 2015)consumer purchasing behavior is affected by four factors, including the following: cultural, social, and psychological factors. Rika (2019)states that religious insights have a significant negative effect on loan interest in the moneylenders. Similarly, Ainnun et al. (2018)found that cultural, social, personal and psychological factors affect people's decision-making on the moneylender's loans. furthermore, Ainnun et al. (2018)used simple regression to find more dominant factor affected people's decision-making towards the moneylenders loans, namely social factors because many affected the important role of a neighborhood, group members and family members, which encouraged people to borrow to the moneylenders. Then the observations of Hudoro \& El Ayyubi (2014)show that there are three other factors that can affect people's decision in choosing loan system, including: formal education, religious education and the absence of other financing alternatives in accordance with sharia (Hudoro \& El Ayyubi, 2014; Sabirin \& Sukimin, 2017).

The importance of this research was reviewed from the level of human needs, either from a conventional point of view or from an Islamic point of view. Conventional theories about human needs are as expressed by Abraham Maslow (psychologist from the United States). His article entitled "A Theory of Human Motivation" in the scientific psychology journal "Pshychological Review" revealed that human needs are classified into five levels (Maslow, 2013). The three large categories and the five small categories of human needs according to Abraham Maslow are as described below:

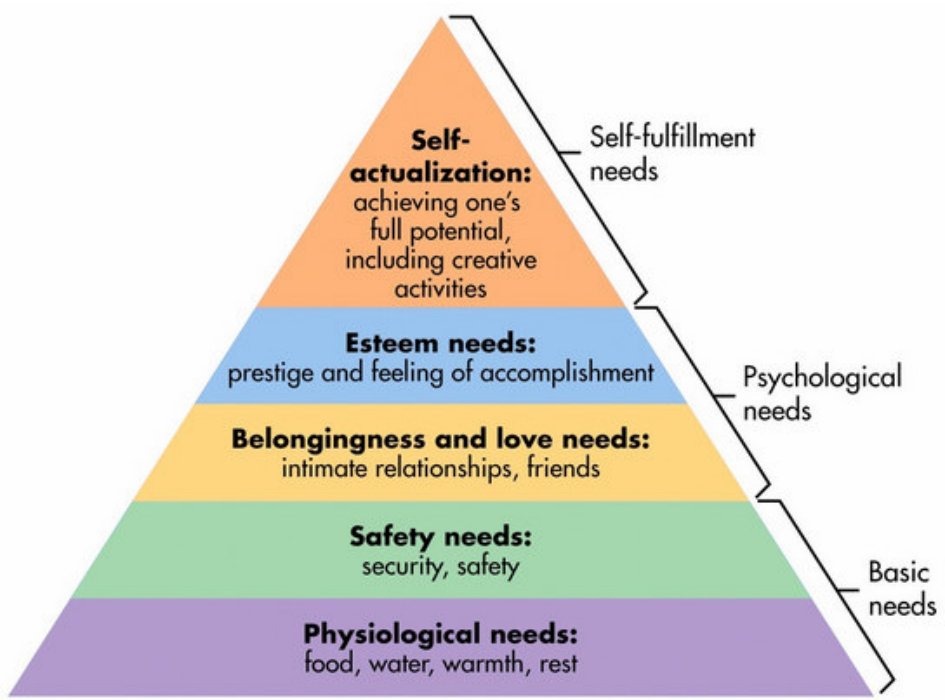

Figure 1 Pyramid of human necessity (Maslow, 2013)

This research focused on providing an evidence related to the employee dependency in the process of borrowing money with interest (loan) to the moneylenders. So the purpose of this research was to analyze and describe A Strategy to Overcome Loan Dependency to the Moneylenders (Research of Employees at Industrial Companies in Banten Province).

\section{Method}

The research approach was used quantitative deductive methods (empirical researches) and inductive. Furthermore, 
the basis of the research method in this dissertation was the merging of type of investigation and unit of analysis, because this research analyzed the effect and simultaneous relationship between several variables studied using cross-section type data. Research design was a structured and comprehensive work plan containing relationships between variables arranged in such a way that the results of the research can provide answers to research questions (Sekaran, 1983).

The analysis technique in this dissertation was to use analysis through Structural Equation Modeling or SEM which was then presented and interpreted to answer research questions of strategies to overcome loan dependencyto themoneylenders. Here's an overview of the Structural Equation Modeling (SEM) method described on the story board below:

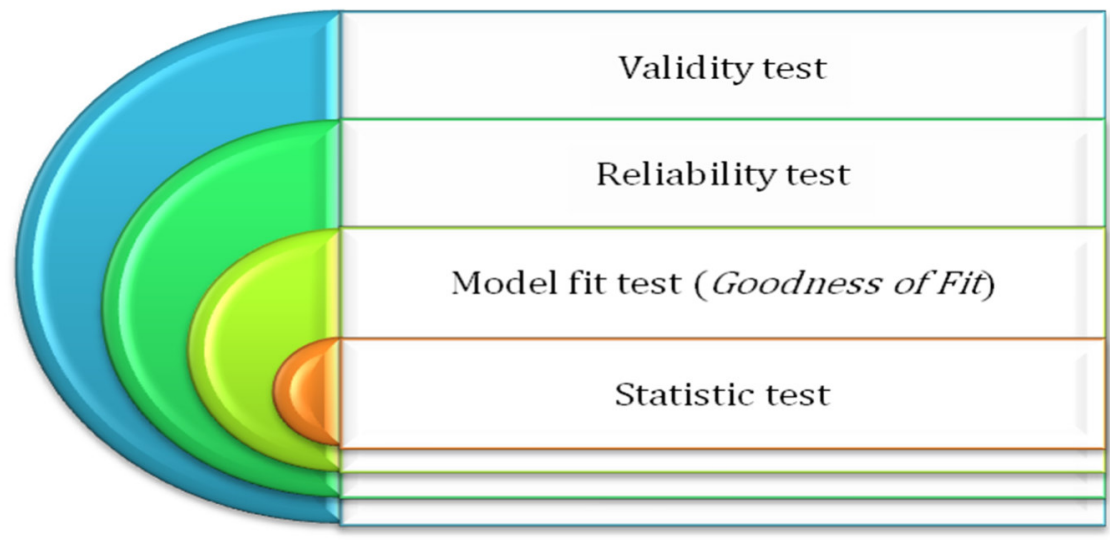

Figure 2 Structural equation modeling (SEM) method

\section{Result}

A common characteristic contained in this research was that respondents are employees of the industrial companies in Banten Province domiciled in eight regencies / cities in Banten and they have done loan transactions to the moneylenders in accordance with the topics of this research. Another common characteristic that respondents have in this research was that they are Muslim because this research would look at how respondents perceive loan taking on the moneylenders according to Islamic law, so there is a need for similar characteristics in the beliefs embraced by the respondents.

The results of this research based on their gender showed that there were $67.5 \%$ of respondents were females. This was because the most labor-intensive industrial companies in Banten have $75 \%$ female employees. Based on the age of the largest respondents in the age range between 21 to 35 years, which was $50.8 \%$ in the productive age. The next largest proportion were respondents aged 36 to 40 years, which was $24.6 \%$ employees of this age had started to charge a lot in their household life, such as children's school fees and others. Meanwhile, based on the level of education, it showed that the largest proportion of respondents' education was high school and below. Respondents who were educated senior high school was $54.7 \%$, followed by junior high school educated was $24.8 \%$, college graduated was $14.5 \%$ and elementary school educated was $6 \%$, this was possible because the average employee of industrial companies in Banten education level was still at the high school level and below.

Further classification by looking at the income level showed that the largest proportion of respondents' income was between IDR 3,760,000, - up to IDR 4,500,000, - which was 45.3\%. This was possible because the Regional Minimum Wage (UMR) in Banten Province was the lowest IDR 2,710,654,- per month in Pandeglang district and the highest was IDR 4,246,081 per month which was the regional minimum wage in Cilegon city. While based on the level of lightness of lending to the moneylenders, the largest proportion of respondents borrowed money to the moneylenders was more than three times that of $31 \%$. This indicated that respondents tend to repeat in lending money to the moneylenders.

Based on the location of loan to the moneylenders as much as $73 \%$ of respondents who made a transaction at work. This indicated that respondents were very easy to borrow money to the moneylenders because it was in the work environment. The source of information where to borrow money obtained from workmates was the biggest answer of $81 \%$. This was possible because in practice the moneylenders cooperate with employees who work in Industrial companies in Banten who are used as the partners or agent of the moneylenders. While the loan disbursement time is usually the most respondents answer takes 31 to 60 minutes could get a loan from the moneylenders that was $30.5 \%$. Then the reason for borrowing money to the moneylenders was because of an urgent need that was $50.2 \%$ of respondents. As well as the need to borrow money to the moneylenders was to pay the debt of $37.7 \%$. All of these data came from the data that had accumulated the most data of respondents who answered the questionnaire.

The research on SEM model as a whole consists of seven variables and there are 21 indicators (Irawan \& 
Waluyo, 2020). Based on the results of processing the above variables, a structural model is further built in accordance with the research framework. The following is a Path Diagram image consisting of religiosity factor (RI), Social Factor (FS), Cultural Factor (FB), Personal Factor (FP), Psychological Factor (PK), Factors of Existence of (SMFI) (KL), and loan decisions to the money lenders (KD). The model fit test aimed to see how well the model was fit (Goodness of fitness or GOF). The absolute model fit size aimed to determine the predicted degree of the overall model against the correlation and covariant matrix consisting of RMSEA and GFI. RMSEA aimed to measure parameter value deviations in a model with a covariant matrix of populations, so it can be said that RMSEA is the most informative model measurement indicator. Wijanto (2008)formulated cutt-off guidelines for the interpretation of model test results is presented in Table 1.

To find out if the proposed measurement model was fit or not with the data, a measurement model conformity test was carried out. Once it was known that the model was good, then the researcher must also looked at how each indicator contributes, dimensions, as well as the level of validity and reliability of the model. The overall model has good construction reliability with $\mathrm{CR}$ and VE of $93.9 \%$ and $62.8 \%$ respectively, where CR and VE values met the standard requirements or have been declared valid. Where CR is declared valid if the value $>70 \%$ and $\mathrm{VE}$ is declared valid if it is $>50 \%$. All constructs used to form a research model meet the established goodness of fit criteria. This value indicated the absence of the differences between the sample covariant matrix and the estimated covariant matrix of the population, thus the constructs in the research model could be accepted as fit model shapers. Table 1 Cut-off guidelines for interpretation of measurement model and structural model test results.

\begin{tabular}{|c|c|c|c|}
\hline GOF & Cut off Value & $\begin{array}{l}\text { Value of } \\
\text { The } \\
\text { Research }\end{array}$ & Description \\
\hline$C h i$-square $\left(\chi^{2}\right)$ & Preferably small from Df & 337.89 & \\
\hline Df & & 161 & \\
\hline $\begin{array}{l}\text { Chi-square } \\
\left(\chi^{2}\right) / \mathrm{df}\end{array}$ & $\begin{array}{l}\leq 3 \\
(2: 1 \text { (Tabachnik and Fidell 2007) and } 3: 1 \text { (Kline 2005) }\end{array}$ & 2.098 & good fit \\
\hline $\begin{array}{l}\text { Probability (P- } \\
\text { value) }\end{array}$ & $\geq 0.05$ & 0.0000 & good fit \\
\hline RMR & $\begin{array}{l}\text { Good models have small RMR (Tabachnik and Fidell } \\
2007 \text { ), } \leq 0.05 \text { or } 0.08 \text { (Hair et al. 2007) }\end{array}$ & 0.0638 & good fit \\
\hline RMSEA & $\leq 0.08$ & 0.078 & good fit \\
\hline GFI & $\geq 0.90$ & 0.848 & good enough \\
\hline AGFI & $\geq 0.90$ & 0.781 & good enough \\
\hline CFI & $\geq 0.90$ & 0.977 & good fit \\
\hline NFI & $\geq 0,90$ & 0.956 & good fit \\
\hline NNFI & $\geq 0.90$ & 0.970 & good fit \\
\hline RFI & $\geq 0.90$ & 0.942 & good fit \\
\hline IFI & $\geq 0.90$ & 0.978 & good fit \\
\hline
\end{tabular}

To find out if the proposed measurement model was fit or not with the data, a measurement model conformity test was carried out. Once it was known that the model was good, then the researcher must also looked at how each indicator contributes, dimensions, as well as the level of validity and reliability of the model. The overall model has good construction reliability with CR and VE of 93.9\% and 62.8\% respectively, where CR and VE values met the standard requirements or have been declared valid. Where CR is declared valid if the value $>70 \%$ and $\mathrm{VE}$ is declared valid if it is $>50 \%$. All constructs used to form a research model meet the established goodness of fit criteria. This value indicated the absence of the differences between the sample covariant matrix and the estimated covariant matrix of the population, thus the constructs in the research model could be accepted as fit model shapers. Based on the results of processing the above variables, a structural model is further built in accordance with the research framework. The following is a Path Diagram Image consisting of the Religiosity Factor(RI), Social Factor (FS), Cultural Factor (FB), Personal Factor (FP), Psychological Factor (PK), Factors of Existence of SMFI (KL), and loan decisions to the money lenders (KD). Based on Figure 4.15 and Figure 4.16 can be seen the amount of effect between variables and their significance. 


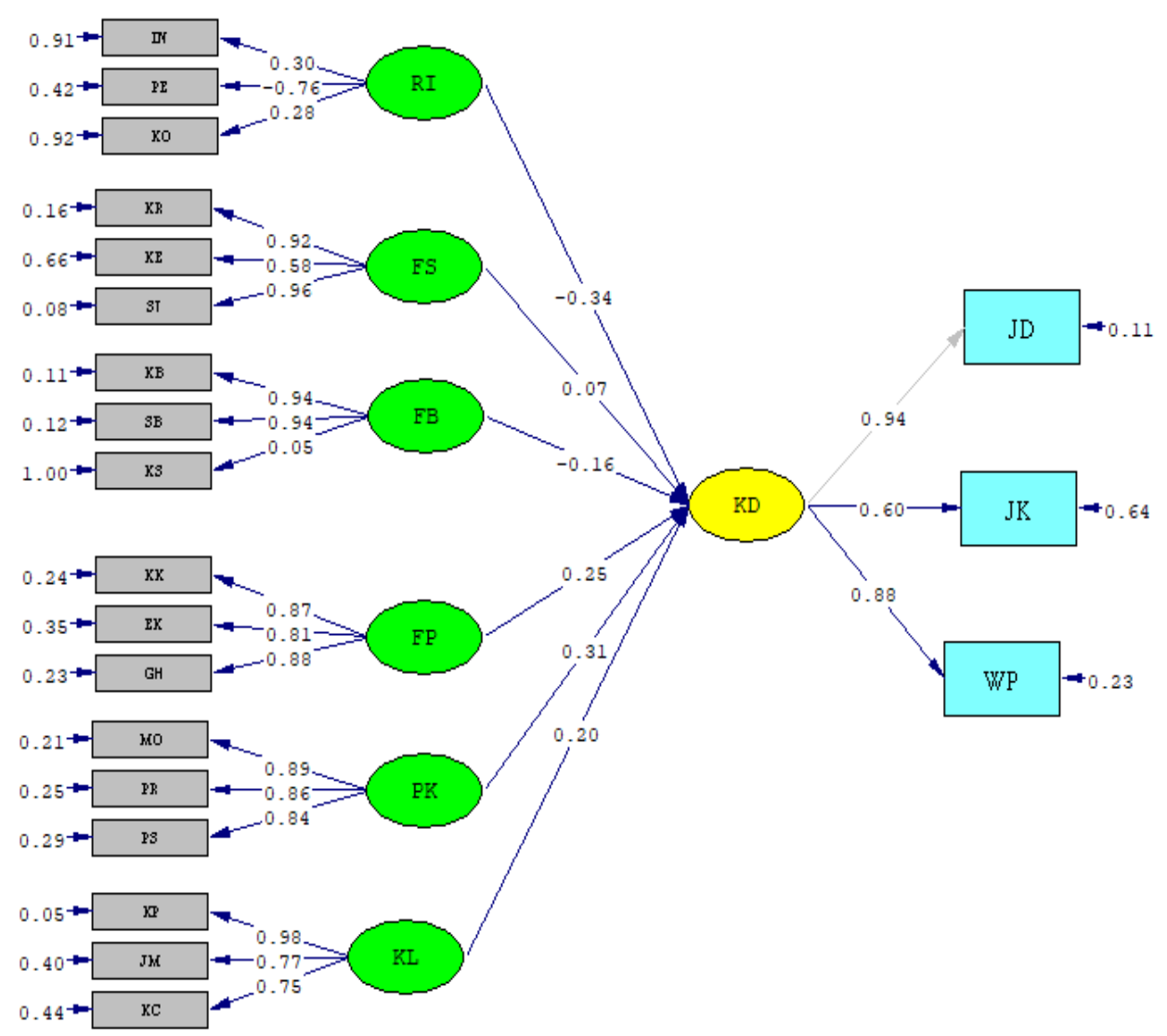

Chi-Square $=337.89, \mathrm{df}=161, \mathrm{P}-\mathrm{value}=0.00000, \mathrm{RMSEA}=0.078$

Figure 3 Output standardized solution SEM Lisrel 8.80 model

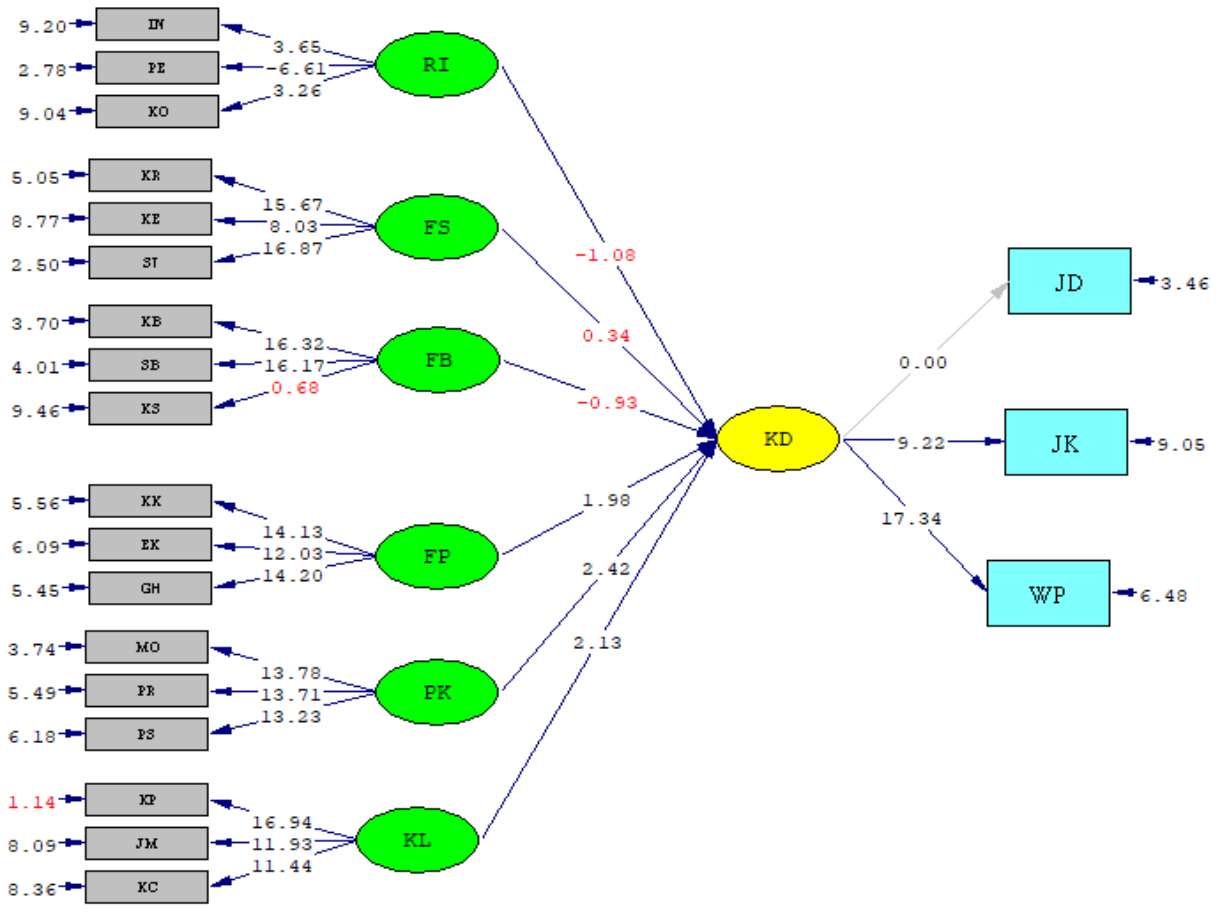

Chi-Square=337.89, df=161, P-value=0.00000, RMSEA $=0.078$

Figure 4 Output t-value SEM Lisrel 8.80 model

In Table. 2 it is known that the SLF value of each variable has been qualified, so it can be said that the Religiosity Factor(RI), Social Factor (FS), Cultural Factor (FB), Personal Factor (FP), Psychological Factor (PK), 
Factors of Existence of SMFI (KL), and loan decisions to the money lenders (KD) have been valid. The overall model has good construction reliability with $\mathrm{CR}$ and VE of $93.9 \%$ and $62.8 \%$ respectively, where CR and VE values meet the standard requirements or have been declared valid. Where CR is declared valid if the value $>70 \%$ and VE is declared valid if it is $>50 \%$. All constructs used to form a research model meet the established goodness of fit criteria. This value indicated the absence of differences between the sample covariant matrix and the estimated covariant matrix of the population, thus the constructs in the research model could be accepted as fit model shapers.

Table 2 Overall model goodness of fit test

\begin{tabular}{|c|c|c|c|}
\hline GOF & Cut off Value & Value of The Research & Description \\
\hline$C h i$-square $\left(\chi^{2}\right)$ & Prefebly small than Df & 337.89 & \\
\hline Df & & 161 & \\
\hline $\begin{array}{l}\text { Chi-square } \\
\left(\chi^{2}\right) / \mathrm{df}\end{array}$ & $\begin{array}{l}\leq 3 \\
(2: 1 \text { (Tabachnik and Fidell 2007) and 3:1 (Kline } \\
2005)\end{array}$ & 2.098 & good fit \\
\hline $\begin{array}{l}\text { Probability (P- } \\
\text { value) }\end{array}$ & $\leq 0.05$ & 0.0000 & good fit \\
\hline RMR & $\begin{array}{l}\text { A good model has a small RMR (Tabachnik and } \\
\text { Fidell 2007), } \leq 0.05 \text { atau } 0.08 \text { (Hair et al. } 2007 \text { ) }\end{array}$ & 0.0638 & good fit \\
\hline RMSEA & $\leq 0.08$ & 0.078 & good fit \\
\hline GFI & $\geq 0.90$ & 0.848 & good enough \\
\hline AGFI & $\geq 0.90$ & 0.781 & good enough \\
\hline CFI & $\geq 0.90$ & 0.977 & good fit \\
\hline NFI & $\geq 0,90$ & 0.956 & good fit \\
\hline NNFI & $\geq 0.90$ & 0.970 & good fit \\
\hline RFI & $\geq 0.90$ & 0.942 & good fit \\
\hline IFI & $\geq 0.90$ & 0.978 & good fit \\
\hline
\end{tabular}

\section{Discussion}

Based on the hypothetical test results and estimation value, it can be seen that religiosity factor variable (RI) does not have a significant effect on loan decision making (KD), because the value of t-value $-1.08<\mathrm{t}$-table $(1.96)$ with a low estimate value with a negative direction of -0.34 . The more religious a person means, the more often carry out orders as a Muslim. Social Factor variable (FS) do not have a significant effect on loan decision making (KD), because the value of $\mathrm{t}$-value $0.34<\mathrm{t}$-table (1.96) with an estimate value of positive direction is 0.07 . These results do not support the research presented by (Nurlaeli, 2017; Sitohang, 2013)where it is explained that social factors have a positive and significant effect on loan decision making.

Variable of Cultural Factor (FB) does not have a significant effect on loan decision making (KD), because the value of $t$-value is $-0.93<\mathrm{t}$-table (1.96) with a negative direction estimate value of -0.16 . It is very broad, so that people's perceptions and interpretations vary, as well as views between individuals on loan taking. Personal Factor Variables (FP) have a significant effect on loan decision making (KD), because the value of t-value is $1.98>$ t-table (1.96) at a real level of 5\% with an estimate value of 0.25 . A person's personality is formed due to a variety of indicators. The higher a person is established in terms of the economy, the lifestyle increases, the higher the decision to do loan. The results of this research were in line with statements (Kotler, 2015; Suarni et al., 2014), a personal factor effect a customer's decision in the taking of loan at a bank. People will take loan for changing circumstances, one of which is related to lifestyle. Lifestyle describes the whole self of someone who interacts with the environment (Bali, 2017).

Table 3 Analysis of relationships between variables

\begin{tabular}{|c|c|c|c|c|c|c|}
\hline \multirow{2}{*}{$\begin{array}{l}\text { Alternative } \\
\text { Hypotheses } \\
\text { (Ha) }\end{array}$} & \multirow[b]{2}{*}{ Path (connection) } & \multirow{2}{*}{$\begin{array}{l}\text { Value } \\
\text { t count } \\
(\geq 1.96)\end{array}$} & \multicolumn{3}{|l|}{ Effect } & \multirow[b]{2}{*}{ conclusion } \\
\hline & & & Direct & Indirect & Total & \\
\hline H1 & $\mathrm{RI} \rightarrow \mathrm{KD}$ & -1.08 & -0.34 & & -0.34 & Rejected \\
\hline $\mathrm{H} 2$ & $\mathrm{FS} \rightarrow \mathrm{KD}$ & 0.34 & 0.07 & & 0.07 & Rejected \\
\hline $\mathrm{H} 3$ & $\mathrm{FB} \rightarrow \mathrm{KD}$ & -0.93 & -0.16 & & -0.16 & Rejected \\
\hline $\mathrm{H} 4$ & $\mathrm{FP} \rightarrow \mathrm{KD}$ & 1.98 & 0.25 & & 0.25 & Accepted \\
\hline H5 & $\mathrm{PK} \rightarrow \mathrm{KD}$ & 2.42 & 0.31 & & 0.31 & Accepted \\
\hline H6 & $\mathrm{KL} \rightarrow \mathrm{KD}$ & 2.13 & 0.2 & & 0.2 & Accepted \\
\hline
\end{tabular}

Psychological Factor variable (PK) has a significant effect on loan decision making (KD), because the value of t-value is $2.42>\mathrm{t}$-table (1.96) with an estimate value of 0.31 . These results were in line with Wiryaningtyas (2019)research where psychological factors proved to have a significant positive effect on loan decisions. 
Psychological factors arise and direct a person to be able to seek satisfaction with the fulfillment of needs (Jatun \& Rizal, 2015) The need for financial security, for example. Variable Existence Factor of SMFI (KL) has a significant effect on loan decision (KD), because the value of $t$-value is $2.13>t$-table (1.96) with an estimate value of 0.2. As a financial institution that serves as an intermediation institution, SMFI in addition to carrying out savings and loan activities but also required to provide awareness of saving and caring for others through Islamic philanthropy to the community (Damayanti et al., 2019; Qadariyah \& Permata, 2017).

This research aimed to obtain empirical evidence about several indicators that have an effect on loan dependency to the money lenders for employees at industrial companies in Banten. Based on the results of the research, it can be concluded the following results: Religiosity Factor (RI) does not have a significant effect on loan decision making (KD). Cultural Factor (FB) do not have a significant effect on loan decision making (KD). Social Factor (FS) do not have a significant effect on loan decision making (KD). Personal Factor (FP) have a significant effect on loan decision making (KD). Psychological Factor (PK) has a significant effect on loan decision making (KD). The Existence factor of SMFI (KL) has a significant effect on loan decision making (KD).

For internal industrial companies in Banten, the researcher proposed a concept to the DKM of the mosque in the company to add to the PKJ (Penolong Kesengsaraan Jamaah/Congregation Misery Helper) activity unit. This activity unit functions as an institution that deals with congregational problems, especially those who have loans to moneylenders and are unable to pay them off, so this PKJ under DKM helps pay off congregational debts to loan sharks with the Qardhul Hasan agreement (a qardh agreement specifically for social purposes) and then the congregation repays the loan. to PKJ according to the agreed time and relieve the congregation. The source of funds used is the money from the congregation's infaq collected every Friday and zakat or alms from the congregation which is managed by the DKM management.

Advice for industrial companies to hold economic activities units such as SMFI and others within the company in order to help employees who are experiencing financial difficulties. Advice for employees of the industrial companies need to do a lot of consideration in taking loan decisions in debt so as not to cause psychological effects such as stress and complicate themselves. Because one of the effects of loan decision making comes from each individual. Repetitive lending behavior will cause a variety of problems that alternate. Further research advice is to expand the variety of research samples, such as considering their demographic characteristics, to see the loan differences offered by the moneylenders in each region, as well as the origin of the moneylenders area itself.

Praise the Lord, God Almighty for all His blessings and love, so this scientific work was successfully completed. The title chosen in the study was A strategy to Overcome Loan dependency to the Moneylenders (Research of Employees at Industrial Companies in Banten Province)

\section{Acknowledgments}

Praise the Lord, God Almighty for all His blessings and love, so this scientific work was successfully completed. The title chosen in the study was A strategy to Overcome Loan dependency to the Moneylenders (Research of Employees at Industrial Companies in Banten Province). On this occasion the authors would like to thank Miyasto \& Hasbi Umar as the supervisory commission for guidance and motivation. The author's appreciation goes to themy late father, my mother, my wife and my children, as well as those present in interview. Finally, I hope this paper is useful for those who need it.

\section{References}

Ainnun, R. U., Tresnati, R., \& Srisusilawati, P. (2018). Kajian Faktor-Faktor yang Dominan Mempengaruhi Keputusan Masyarakat Terhadap Pengambilan Kredit pada Rentenir di Desa Wargamekar Baleendah. Prosiding Hukum Ekonomi Syariah, 904-909.

Bali, M. M. E. I. (2017). Model interaksi sosial dalam mengelaborasi keterampilan sosial. PEDAGOGIK: Jurnal Pendidikan, 4 (2).

Damayanti, L., Budi, S., \& SEI, M. (2019). Optimalisasi Qardhul Hasan Sebagai Wujud Pelaksanaan Corporate Social Responsibility (Studi Kasus Bmt Mitra Ummat). IAIN Surakarta.

Hariyati, M. (2011). Pengaruh Beban Kerja Terhadap Kelelahan Kerja Pada Pekerja Linting Manual Di PT. Djitoe Indonesia Tobacco Surakarta.

Hudoro, P., \& El Ayyubi, S. (2014). Faktor-Faktor yang Memengaruhi Pemilihan Pinjaman dengan Sistem Rente di Desa Studi Kasus: Desa Panulisan Timur Kecamatan Dayeuhulur Kabupaten Cilacap (Periode Tahun 20132014). Al-Muzara'ah, 2(2), 195-217.

Irawan, A., \& Waluyo, M. (2020). Analisis Model Hubungan Kepuasan, Kepercayaan Dan Loyalitas Pelanggan Provider Telkomsel Di Kota Surabaya Menggunakan Structural Equation Modeling (SEM). JUMINTEN, 1(6), 13-24.

Iswanto, Y. (2005). Keserasian Budaya Pada Implementasi Manajemen Sumber Daya Manusia. Jurnal Organisasi dan Manajemen, 1(1), 22-31. 
Jatun, R., \& RIZAL, H. M. (2015). Analisis faktor-faktor yang berpengaruh terhadap keputusan nasabah untuk mengambil pembiayaan pada kospin jasa layanan syariah pekalongan. Fakultas Ekonomika dan Bisnis.

Khakim, L. (2020). Strategi pedagang pasar tradisional untuk mempertahankan praktik jual beli barter dalam perspektif ekonomi syariah. UIN Sunan Ampel Surabaya.

Khasanah, U. (2019). Dampak Praktik Rentenir terhadap Kesejahteraan Pedagang Eceran dalam Perspektif Ekonomi Islam. Jurnal Hukum Ekonomi Syariah, 3(1), 12-26.

Kotler, P. (2015). Manajemen Pemasaran. PT Indeks Kelompok Gramedia.

Maslow, A. H. (2013). A theory of human motivation. Simon and Schuster.

Nurlaeli, I. (2017). Pengaruh Faktor Budaya, Psikologi, Pelayanan, Promosi dan Pengetahuan tentang Produk terhadap Keputusan Nasabah Memilih BPRS di Banyumas. Islamadina: Jurnal Pemikiran Islam, 18(2), 75106.

Parlina, Y. (2017). Praktik Pinjaman Rentenir dan Perkembangan Usaha Pedagang Di Pasar Prapatan Panjalin Majalengka. Inklusif (Jurnal Pengkajian Penelitian Ekonomi Dan Hukum Islam), 2(2), 100-119.

Qadariyah, L., \& Permata, A. R. E. (2017). Peran Lembaga Keuangan Mikro Syariah Dalam Perekonomian Di Indonesia: Studi Teoritik Dan Empirik. Dinar: Jurnal Ekonomi dan Keuangan Islam, 4(1).

Qodarini, A. (2013). Rentenir Dan Pedagang Muslim.(Sebuah Studi Tentang Interaksi Sosial di Pasar Legi Kotagede). BA㧑 esis. UIN Sunan Kalijaga Yogyakarta.

Rika, R. (2019). Pengaruh pengetahuan masyarakat tentang riba terhadap keputusan menggunakan jasa kredit pada rentenir (studi kasus di Kecamatan Padang Gelugur Kabupaten Pasaman). IAIN Padangsidimpuan.

Sabirin, S., \& Sukimin, D. A. (2017). Islamic Micro Finance Melati: Sebuah Upaya Penguatan Permodalan bagi Pedagang Pasar Tradisional. Economica: Jurnal Ekonomi Islam, 8(1), 27-53.

Sekaran, U. (1983). Methodological and theoretical issues and advancements in cross-cultural research. Journal of international business studies, 14(2), 61-73.

Setiowati, N. E. (2017). Pengaruh Program Inklusi Keuangan BMT Al-Falah Terhadap Transaksi Rentenir. AlAmwal: Jurnal Ekonomi dan Perbankan Syari'ah, 9(1).

Sibero, I. K. (2015). Rentenir (Analisis Terhadap Fungsi Pinjaman Berbunga Dalam Masyarakat Rokan Hilir Kecamatan Bagan Sinembah Desa Bagan Batu). Riau University.

Sitohang, U. (2013). Pengaruh Budaya, Sosial, Pribadi, dan Psikologi terhadap Keputusan Pengambilan Kredit di PT Bank Tabungan Pensiunan Nasional. Universitas Atma Jaya Yogyakarta.

Suarni, G. A. P., Tripalupi, L. E., \& Haris, I. A. (2014). Analisis Faktor yang Mempengaruhi Keputusan Nasabah dalam Pengambilan Kredit pada Lpd (Lembaga Perkreditan Desa) Desa Pakraman Manggissari. Jurnal Pendidikan Ekonomi Undiksha, 4(1).

Sulaemang, S. (2015). Hukum Riba Dalam Perspektif Hadis Jabir ra. Al-’Adl, 8(1), 156-171.

Tarmizi, E. (2017). Muamalat Kontemporer (14 ed.). PT. Berkat Mulia Insani.

Wahab, F. (2017). Riba: Transaksi Kotor Dalam Ekonomi. Iqtishodia: Jurnal Ekonomi Syariah, 2(2), $26-41$.

Wijanto, S. H. (2008). Structural equation modeling dengan Lisrel 8.8. Yogyakarta: Graha Ilmu.

Wiryaningtyas, D. P. (2019). Pengaruh Keputusan Nasabah Dalam Pengambilan Kredit pada Bank Kredit Desa Kabupaten Jember. GROWTH, 14(2), 49-57.

\section{Copyrights}

Copyright for this articleis retained by the author(s), with first publication rights granted to the journal. This is an open-access article distributed under the terms and conditions of the Creative Commons Attribution license (http://creativecommons.org/licenses/by/3.0/). 